Research article

\title{
Proteomic evaluation of coffee zygotic embryos in two different stages of seed development
}

\author{
Octavio L. Franco ${ }^{\mathrm{a}, *}$, Patrícia B. Pelegrini ${ }^{\mathrm{a}}$, Clarissa P.C. Gomes ${ }^{\mathrm{a}}$, Andréa Souza ${ }^{\text {a }}$, Fabio T. Costa ${ }^{\mathrm{a}}$, \\ Gilberto Domont $^{\mathrm{b}}$, Betania F. Quirino ${ }^{\mathrm{a}, \mathrm{e}}$, Mirian T. Eira ${ }^{\mathrm{d}}$, Ângela Mehta ${ }^{\mathrm{c}}$ \\ ${ }^{a}$ Centro de Análises Proteômicas e Bioquímicas, Programa de Pós-Graduação em Ciências Genômicas e Biotecnologia, Universidade Católica de Brasília, Brasília - DF, Brazil \\ ${ }^{\mathrm{b}}$ Universidade Federal do Rio de Janeiro, Rio de Janeiro, RJ, Brazil \\ ${ }^{\mathrm{c}}$ Embrapa Recursos Genéticos e Biotecnologia, Brasília - DF, Brazil \\ dembrapa Café, Brasília - DF, Brazil

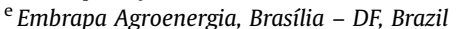

\section{A R T I C L E I N F O}

\section{Article history:}

Received 31 March 2009

Accepted 31 August 2009

Available online 8 September 2009

\section{Keywords:}

Coffee

Proteome

Plant development

Zygotic embryos

\begin{abstract}
A B S T R A C T
Coffee seed development is accompanied by severe modifications in water soluble proteins, several of these being associated to a specific developmental stage. For this reason, a proteomic approach has been used to describe spatial-temporal proteome modifications in zygotic embryos at different stages of seed development. Embryos from Coffea arabica seeds were harvested in two different developmental stages: stage 1 at 210 days after anthesis and stage 2 at 255 days. Total proteins were extracted and submitted to 2-DE. From these gels, several spots were identified by mass spectrometry including kinases, MYB transcription factor and enzymes involved in metabolic pathways. All proteins identified seem to affect coffee development in different ways, being directly involved in plant growth or used as an intermediate in some metabolic pathway that, indirectly, will influence coffee development. This is the first work using two-dimensional electrophoresis followed by mass spectrometry analyses that evaluates the expression of proteins during coffee zygotic embryos development. Data here reported supply some light over coffee development and could be used in a near future to improve coffee plants' growth and development by molecular strategies.
\end{abstract}

(c) 2009 Elsevier Masson SAS. All rights reserved.

\section{Introduction}

The two coffee species most commonly cultivated in the world are Coffea arabica and Coffea canephora. Due to the economic and agricultural importance of coffee, several studies have been accomplished to genetically improve this grain. A special focus has been given, for example, to the identification of the genes encoding methyltransferases, which seem to have crucial importance for caffeine biosynthesis [1]. Furthermore, some studies are also related to increase coffee production or to improve tolerance to biotic and abiotic stresses. Earlier reports showed the identification and characterization of $C$. canephora leaf compounds such as caffeoylquinic acids involved in abiotic stress response and also plant development [2]. The comparative evaluation of caffeine, chlorogenic acids, fat, trigonelline and sucrose was carried out in order to shed some light over coffee resistance/susceptibility toward plant pests [3].

\footnotetext{
* Correspondence to: Dr. Octavio L. Franco, SGAN Quadra 916, Módulo B, Avenida W5 Norte 70, 790-160 - Asa Norte, Brasília-DF, Brazil. Fax: +55 6133474797.

E-mail address: ocfranco@pos.ucb.br (O.L. Franco).
}

Although some papers compare coffee resistance against biotic and abiotic stresses, few reports aim to study the development of coffee from a molecular perspective [4]. One example consists on the evaluation of gibberellins and ethylene in coffee seeds and seedlings [5,6]. Gibberellins could change coffee seed germination, causing cell death in the embryo and leading to inhibition of radicle protrusion [1].

Proteomics permits qualitative and quantitative measurements of a great number of proteins that are directly involved in cellular biochemistry, providing accurate analysis of the cell state or system changes during growth, development, and response to environmental factors. Due to the fact that proteomics is able to reveal both chemical complexity and biological dynamics, it allows functional information of the biochemical processes underlying phenotypes that are not accessible or predictable by other means [7]. Thousands of different proteins can be visualized in a 2D gel, allowing an overall analysis of the total content of proteins expressed in an organism [8]. The identification of proteins can be performed by mass spectrometry which determines molecular masses with great accuracy [8]. However, only few studies of coffee using proteomics and $2 \mathrm{D}$ gels have been reported [36,37]. One of these showed the 
comparison of green and roasted coffee beans to identify the differences that lead to flavor development [9].

In this work, coffee zygotic embryos from $C$. arabica seeds harvested in two different developmental stages were evaluated by proteomic analyses aiming to study protein expression patterns. Water soluble seed proteins were extracted and submitted to 2-DE and several spots were identified by mass spectrometry. The identification of these proteins contributes to the understanding of the molecular mechanisms of coffee development. In the future, this information may be used to improve coffee plants' growth and development by molecular strategies.

\section{Materials and methods}

\subsection{Zygotic embryos and protein extraction}

C. arabica fruits of the Catuaí Vermelho IAC-99 cultivar were collected at two developmental stages: stage 1 at 210 days after anthesis (DAA) and stage 2 at 255 DAA. Stage 1 consists of 210-220 days after anthesis, which corresponds to the developmental stage when the germinability is acquired. Moreover, Stage 2 is $250-260$ days after anthesis and was also defined as a stage in which germinability is vigorous, especially in metabolic processes [38]. According those same authors [38], both stages represent different contrasting developmental stages of coffee fruit and several deep modifications occur at the physiological and molecular level. Embryos were isolated and further used for protein extraction. Each sample was separately grinded in a liquid nitrogen pre-cooled mortar by using a pestle and water-soluble proteins were extracted according to the De Mot and Vanderleyden [10] protocol in the presence of inhibitor cocktail (GE HealthCare) at a standard concentration of $1 \mathrm{mM}$. Approximately $0.1 \mathrm{~g}$ of the resulting ground tissue was placed into a $1.5 \mathrm{~mL}$ tube with $1 \mathrm{~mL}$ of extraction buffer consisting of $0.7 \mathrm{M}$ sucrose, $0.5 \mathrm{M}$ Tris- $\mathrm{HCl}, 30 \mathrm{mM} \mathrm{HCl}, 50 \mathrm{mM}$ EDTA, $0.1 \mathrm{M} \mathrm{KCl}$ and $40 \mathrm{mM}$ DTT. An equal volume of phenol was added and after $15 \mathrm{~min}$ of vigorous shaking, the sample was centrifuged at $4000 \times g$ and re-extracted twice with the extraction buffer. Proteins were precipitated in 5 volumes of $0.1 \mathrm{mM}$ ammonium acetate in chilled methanol at $-20{ }^{\circ} \mathrm{C}$ for $2 \mathrm{~h}$. Precipitates were washed with acetone and resuspended in $40 \mu \mathrm{L}$ of GE HealthCare lysis buffer. The protein content was estimated according to Bradford [11].

\subsection{Gel electrophoresis analyses}

Isoelectric focusing and molecular mass separation were conducted according to Gorg et al. [12], using $13 \mathrm{~cm}$ immobilized pH gradient (IPG) strips with a pH range of 3-11 and a Multiphor II electrophoresis system (GE HealthCare). Samples were precipitated using a 2D Clean-Up Kit (GE HealthCare) and approximately $600 \mu \mathrm{g}$ of total protein were resuspended in $250 \mu \mathrm{L}$ solution of $2 \%$ CHAPS, $8 \mathrm{M}$ urea, $2 \mathrm{M}$ thiourea, $1 \%$ dithiothreitol (DTT), traces of bromophenol blue and 1\% IPG Buffer. Protein concentration was calibrated by Bradford [11] and also by Qubit fluorescence standard kit (Invitrogen) according to the manufacturer manual, where strips were loaded with identical protein quantities. Strips were hydrated in this solution for $16 \mathrm{~h}$. Isoelectric focusing was carried out in gradient mode for $30 \mathrm{~min}$ at $500 \mathrm{~V}, 30 \mathrm{~min}$ at $1000 \mathrm{~V}, 90 \mathrm{~min}$ at $3500 \mathrm{~V}$ and $6 \mathrm{~h}$ at $3500 \mathrm{~V}$, at $2 \mathrm{~mA}$ and $5 \mathrm{~W}$. After the first dimension, strips were equilibrated in a solution of $1.5 \mathrm{M}$ Tris- $\mathrm{HCl}$ pH 8.8, 6 M urea, 1\% DTT, 30\% glycerol, traces of bromophenol blue and $2 \%$ SDS for $15 \mathrm{~min}$. A second dimension was performed in $18 \times 16 \times 0.1 \mathrm{~cm}$ SDS-PAGE $12 \%$ gels, as described by Laemmli [13] with bromophenol blue used as tracking dye. Electrophoresis was conducted on a Hoefer system (GE HealthCare) at $250 \mathrm{~V}, 50 \mathrm{~mA}$ and
$10 \mathrm{~W}$ for $6 \mathrm{~h}$. Gels were silver stained according Blum et al. [14]. The broad range isoelectric point marker (GE HealthCare) was also used for posterior pI identification on gels as well molecular weight markers (GE HealthCare). Each protein sample was analyzed in triplicate. Gels were digitalized using the scanner HP Scanjet Model 8290 and further analyzed with the BioNumerics software v. 4.5 (Applied-Maths). First, calibration with a gray scale was necessary to transform gray levels into values for each pixel of the gel picture. The calibration method used a calibration curve from BioNumerics software. All gel pictures were analyzed as tiff files. The six gel images were placed in one folder and the wizard detection method proposed by the software was used for spot detection. Automatically detected spots were manually checked, and some of them manually added or removed according to the size $(>0.2 \mathrm{~cm}$ was used as the cutoff limit for inclusion), shape (circular) and density $\left(>2\right.$ pixel $\mathrm{cm}^{-1}$ ). Following the detection procedure, the normalization step was carried out to attribute a common protein identity for identical spots from different gel images. For this procedure, a reference gel was constructed and automatically matching options of BioNumerics software were used. For each sample, when a protein was detected in all gel images, this protein was automatically added to the reference gel.

\subsection{Protein digestion}

The most intense spots were excised from gels using a scalpel. A protein in-gel digestion with trypsin Gold (Promega) was conducted following the protocol described by Shevchenko et al. [15]. Briefly, $300 \mu \mathrm{l}$ of $100 \%$ acetonitrile was added to the tubes and incubated for $5 \mathrm{~min}$. Supernatant was removed and spots were dried in a SpeedVac for $5 \mathrm{~min}$. Samples were incubated for $60 \mathrm{~min}$ at $56{ }^{\circ} \mathrm{C}$ in a solution containing $50 \mu \mathrm{L}$ of $10 \mathrm{mM}$ DTT and $100 \mathrm{mM}$ $\mathrm{NH}_{4} \mathrm{HCO}_{3}$. The solution was replaced with $50 \mu \mathrm{L}$ of $55 \mathrm{mM}$ iodoacetamide and $100 \mathrm{mM} \mathrm{NH}_{4} \mathrm{HCO}_{3}$ and incubated in the dark for $45 \mathrm{~min}$. Spots were rinsed twice with MilliQ water (Millipore) for $10 \mathrm{~min}$, and exposed to $100 \mu \mathrm{L}$ of $100 \%$ acetonitrile for $5 \mathrm{~min}$. Excess acetonitrile was removed and again spots were dried in a SpeedVac for $5 \mathrm{~min}$. Protein digestion was carried out using $650 \mathrm{ng}$ trypsin diluted in $50 \mu \mathrm{L}$ of $50 \mathrm{mM} \mathrm{NH}_{4} \mathrm{HCO}_{3}$ and $6 \mathrm{mM} \mathrm{CaCl}_{2}$, with overnight incubation at $37{ }^{\circ} \mathrm{C}$. The supernatant was used for mass spectrometry analysis.

\subsection{Protein identification by mass spectrometry}

Monoisotopic masses of the molecular components from digested peptides ranging from $\mathrm{m} / \mathrm{z} 600$ to 6000 were determined by mass spectrometry using a 4700 MALDI-TOF/TOF (Applied Biosystems, Framingham, MA) controlled by the manufacturer's softwares. A sample of $2 \mu \mathrm{L}$ was mixed with $6 \mu \mathrm{L}$ of $0.1 \% \alpha$-cyano-4hydroxycinnamic acid, $0.1 \%$ trifluoroacetic acid and acetonitrile (1:1). A volume of $0.5 \mu \mathrm{L}$ was applied to a MALDI's plate and air dried at room temperature. The spectrometer was operated in linear mode for MS acquiring and reflected mode for MS/MS acquisitions using modulated power with 200 random shots. Data was saved in standard Bruker's software format. Spots were identified using Peptide Mass Fingerprinting (PMF) and de novo sequencing. The mass list for each sample was analyzed using the program MASCOT v2.1.0, Matrix Science, London (http://www. matrixscience.com) assuming one missed cleavage, carboxymethylation and methionine oxidation as modifications. The lists of masses were compared against the non-redundant NCBI database. Results were evaluated by comparing the molecular mass and isoelectric point of the hit of highest score to data here reported observed in 2D gels. De novo sequencing was conducted manually, subtracting the masses from y series and comparing to amino acid 
masses. Sequences were then compared to the Swiss-Prot Data base (www.expasy.org) using the MPSrch tool from the European Institute of Bioinformatics (EBI). Only protein hits with molecular mass and isoelectric point values similar to those found on gels, together with coverage, similarity and tryptic digestion pattern were considered as a match.

\section{Results and discussion}

\subsection{Comparative analyses of protein maps}

Water soluble proteins were extracted from zygotic embryos at two different developmental stages of $C$. arabica seeds. Stage 1 corresponding to 210 days after anthesis (DAA) and stage 2-255 DAA. Stage 1 is directly related to developmental stage of starting germinability. Moreover, Stage 2 was distinct as a stage in which germinability is vigorous, especially in metabolic processes [38]. After extraction, two-dimensional gels from coffee embryos were obtained (Fig. $1 \mathrm{~A}$ for stage 1 and $\mathrm{B}$ for stage 2), using a $\mathrm{pH}$ range varying from 3.0 to 11.0 and molecular mass varying from 14 to $181 \mathrm{kDa}$ (Fig. 1A for stage 1 and B for stage 2). Protein maps obtained from two independent samples were scanned and further compared to identify differences in protein expression using the BioNumerics software. Each protein sample was analyzed in triplicate and corresponding gels showed correlation values higher than 0.9 (data not shown).

Two-dimensional gels from the first stage of coffee seed development analyzed showed 185 spots, distributed throughout the gel. pI and molecular masses of identified proteins varied from 4.5 to 9.0 and from 10 to $140 \mathrm{kDa}$, respectively (Fig. 1A). Most of the spots were situated between pIs 5.0 and 7.0 , where the most abundant proteins are also located. A similar profile was observed for stage 2 of $C$. arabica seed development (Fig. 1B), where a high quantity of spots were resolved, showing proteins with $\mathrm{pH}$ varying from 4.5 to 9.0, and molecular masses ranging from 10 to $115 \mathrm{kDa}$ (Fig. 1B). Nevertheless, only differential spots were chosen for protein identification. Among all spots, only 10 proteins were observed in one or another developmental stage at triplicate gels. Stage 1 showed four differential proteins expressed (spots1-4, Fig. $1 \mathrm{~A}$ ) and at stage 2D-E, six proteins were differentially expressed (spots 5-10, Fig. 1B). These ten spots were further identified by MS analyses as described above.

\subsection{Mass spectrometry protein identification at earlier stage embryos}

Spots were sliced, trypsinized, submitted to mass spectrometry analyses (MALDI-ToF) and further analyzed. They were mainly situated between $\mathrm{pH} 4.5$ and 8.0 and with molecular mass varying from $13 \mathrm{kDa}$ to $85 \mathrm{kDa}$ (Table 1). Mascot and BLAST analyses of these protein spots revealed clear similarities to proteins involved in plant development and germination (Table 1).

Protein spot 1 , observed only at stage 1 , showed similarity to U1 snRNP 70K protein from Arabidopsis thaliana (Table 1) [16]. This protein was earlier described as being involved in pre-RNAs splicing, and there are some evidences that U1 snRNA genes are differently expressed during plant development [17]. U1 snRNAs were previously described in bean [18], pea [19], tomato [20], wheat [21] and potato [29]. They have been shown to be encoded by multiple genes that occur in clusters [22]. A U1 snRNA is the most abundant snRNA in eukaryotic cells and is essential for pre-mRNAs splicing [23], especially at earlier stages of development. Furthermore, two different spots of coffee were also identified by fingerprint analyses as protein kinases, showing similarities to proteins from Petroselinum crispum and A. thaliana (Table 1, spot 2 and 7) [34]. Mitogen-
A

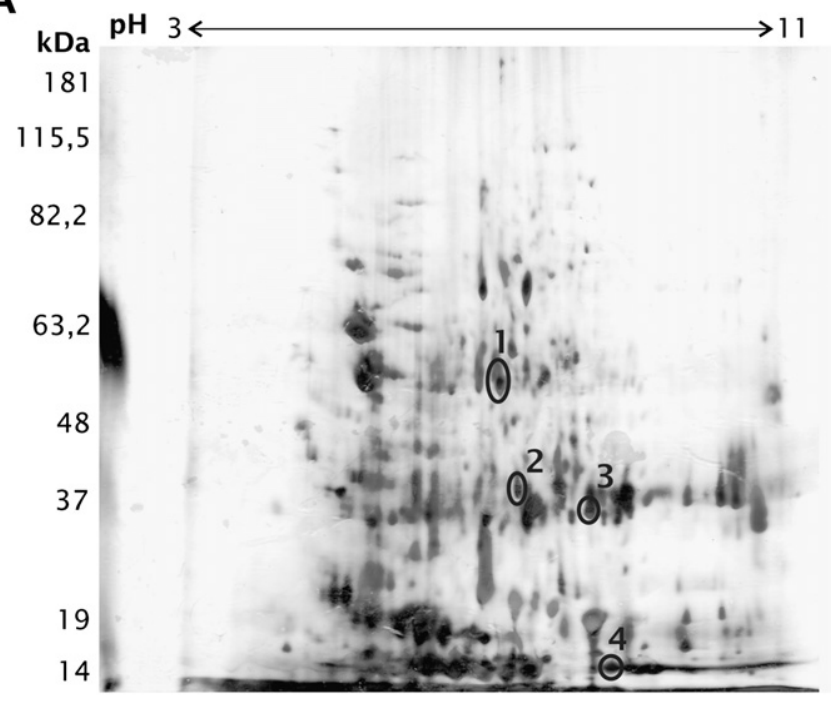

B

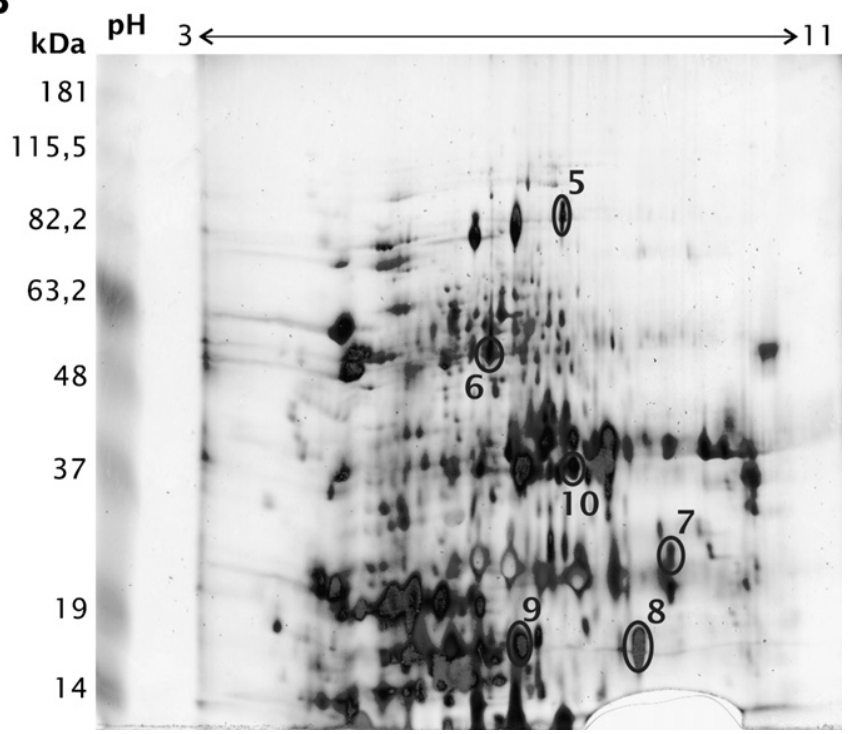

Fig. 1. Two-dimensional gels of $C$. arabica embryos at the developmental stage 1 (210-220 days after anthesis - A) and 2 (250-260 days after anthesis - B). Numbers represent the differential spots further identified by mass spectrometry technology. Numbers on the left side of the gel correspond to the molecular masses. Numbers on the top correspond to $\mathrm{pI}$ range.

activated protein kinases (MAPKS) are activated after phosphorylation of tyrosine and threonine residues, and their pathways can be stimulated by several reasons, including growth factors, cytokines, irradiation and changes in osmolarity [35]. In fact, it is difficult to relate the kinase activity to a single developmental stage, where spot 2 appears at stage 1 (Fig. 1A) and spot 7 at stage 2 (Fig. 1B), since this enzyme class could be involved in a wide diversity of processes.

Protein spot 3, also recovered from stage 1 gels showed similarity to an oxygen evolving enhancer protein from Bruguiera gymnorhiza (Table 1). This protein has been related to plant metabolism, growth and development, as well as to signaling defense against the presence of pathogens [29], being this presence at earlier stages an indicative of intense occurrence of metabolic processes. Finally, the last protein spot identified at stage 1 , numbered as 4 , corresponding to one more protein of $C$. arabica from stage 1 identified by 2D-electrophoresis, showed homology to an ATP synthase from Trachycystis flagellaris 
Table 1

Proteins identified from C. arabica embryos in different developmental stages. Peptide mass fingerprint (PMF) was conducted using the software Mascot. Mpsrch score, sequence, $\mathrm{pI}$ and molecular mass were used for protein identification. Proteins that showed no sequence, identified by PMF, were only identified by Mascot scores.

\begin{tabular}{|c|c|c|c|c|c|c|c|c|}
\hline Spot & Protein class (species) & $\begin{array}{l}\text { Accession } \\
\text { number }\end{array}$ & Score & $\begin{array}{l}\text { Gel } \\
\text { molecular } \\
\text { mass (kDa) }\end{array}$ & $\begin{array}{l}\text { Theoretical } \\
\text { molecular } \\
\text { mass (Da) }\end{array}$ & Gel pI & $\begin{array}{l}\text { Theoretical } \\
\text { pI }\end{array}$ & Partial sequence \\
\hline 1 & U1 snRNP 70K protein (Arabidopsis thaliana) & S71267 & 38 & $45-50$ & 50415 & $5.5-6.5$ & 6.6 & $\begin{array}{l}\text { LYITQEGVRSPFSSK } \\
\text { FPGQTESTLSAEIELIR } \\
\text { TVPNWRPRR }\end{array}$ \\
\hline 2 & $\begin{array}{l}\text { Mitogen-activated protein kinase } 2 \\
\text { (Petroselinum crispum) }\end{array}$ & gi|42601214 & 41 & $30-40$ & 39458 & $5.0-6.0$ & 5.6 & $\begin{array}{l}\text { GLWYLHHEK } \\
\text { KRPSANELLR }\end{array}$ \\
\hline 3 & $\begin{array}{l}\text { Oxygen evolving enhancer protein } 1 \text { precursor } \\
\text { (Bruguiera gymnorhiz) }\end{array}$ & Q9LRC4_9ROSI & 33 & $30-40$ & 35340 & $6.0-7.0$ & 6.5 & NTSSSTGKITLGVTK \\
\hline 4 & ATP synthase beta subunit (Trachycystis flagellaris) & Q7YL94_9BRYO & 41 & $<20$ & 12988 & $7.0-8.0$ & 7.9 & TQIIGPVLDVTFSR \\
\hline 5 & Hypothetical protein (Oryza sativa) & gi|115484731 & 27 & $75-85$ & 83526 & $6.5-7.5$ & 7.6 & PMF \\
\hline 6 & $\begin{array}{l}\text { Ribulose-1.5-biphosphate carboxylase/oxygenase } \\
\text { (Ceratopteris thalictroides) }\end{array}$ & T03448 & 41 & $45-55$ & 41659 & $5.5-6.5$ & 5.2 & IPPAYSKTFLGPPHGIQVER \\
\hline 7 & Putative protein kinase (Arabidopsis thaliana) & gi|110739818 & 42 & $20-30$ & 36869 & $4.5-5.5$ & 6.3 & $\begin{array}{l}\text { CWQTDSKLRPSFAEIMASLK } \\
\text { RLDIPDFVDPAIADLISK } \\
\text { MKHSTYLSSK }\end{array}$ \\
\hline 8 & Glutaredoxin family protein (Arabidopsis thaliana) & gi|15218686 & 52 & $<20$ & 14989 & $5.0-6.5$ & 5.7 & TDNAVKNHWHVIMAR \\
\hline 9 & MYB transcription factor R2R3 type (Populus tremula) & gi|31980093 & 30 & $<20$ & 21908 & $7.5-8.5$ & 9.5 & PMF \\
\hline 10 & СТP: phosphocholine cytidyltransferase (Brassica napus) & gi| $\mid 1418125$ & 28 & $35-45$ & 38463 & $4.5-5.5$ & 5.0 & PMF \\
\hline
\end{tabular}

(Table 1) [24]. ATP synthases catalyze the synthesis of ATP from ADP at bacterial, mitochondrial and chloroplast membranes [25]. This is the main and last process for energy production in all live organisms, composed by an enzyme complex [26].

\subsection{Mass spectrometry protein identification at latter stage embryos}

As in the first stage, the second one also generates differential proteins. Initially, some protein spots showed clear similarity to proteins not directly related to plant growth and development. For example spot 5 (Fig. 1B, Table 1) showed similarity to a hypothetical protein from Oryza sativa. Moreover, a ribulose-1,5-biphosphate carboxylase/oxygenase was identified on spot 6 from stage 2 C. arabica (Table 1). Ribulose-1,5-biphosphate is one of the components of Calvin-Benson-Bassham cycle, being the product of catalysis by a phosphoribulokinase [28]. 1,5-Biphosphate carboxylase/oxygenases occupies a central position in the carbon global cycle and is a key enzyme for conversion of inorganic carbon dioxide into organic cellular components [28], and it is unusual that this protein has also been identified at developmental stage 2 .

A glutaredoxin family protein (spot 8) was also identified at the second stage as being similar to $A$. thaliana molecules (Table 1 , Fig. 1B). Earlier studies described those genes encoding glutaredoxins are related to defects in sepal and petal development in flowers, as well in oxidative stress in plants [27], being commonly found when embryos start cell differentiation. Furthermore, a fingerprint analysis of spot 9 revealed a protein with similarity to MYB transcription factor R2R3 type isolated from Populus sp. [30]. This MYB factor seems to be involved with signaling mechanisms related to secondary wall and lignin formation, as well as to cellulose biosynthesis and xylem development [31,32]. This protein class has been associated with the control of tannin product, being involved in some stage of the proanthocyanidins (PAs) biosynthesis metabolic pathway [33].

Finally, protein spot 10 (Table 1, Fig. 1B) showed similarity to CTP: phosphocholine cytidyltransferase. This enzyme is a rate-limiting enzyme in biosynthesis of phosphatidylcholine in plant cells [39]. The role of complex lipids in plant physiology and cellular metabolism has remained under debate. The biosynthesis of phosphatidylcholine (PC) in plants is of particular interest, since some freezing tolerance has been correlated with changes in phospholipid content of plant systems [40]. Nevertheless, this is a new observation of a CTP: phosphocholine cytidyltransferase at different plant developmental stages. This fact could occur due a clear modification of lipid content during plant development.

In summary, it could be observed that $C$. arabica presents differential expression of diverse proteins related to development during both stages analyzed. All proteins identified seem to affect directly or indirectly coffee development by different manners, being strictly involved in plant growth or used as an intermediate in some metabolic pathway that could influence coffee germination. Furthermore, the identification of such proteins expressed during two stages of development in $C$. arabica can now be used as an important tool for future experiments. By using genetic engineering techniques, the specific role that each one of these proteins play in coffee embryo development can now be studied, improving coffee embryo development.

\section{Acknowledgments}

The authors are thankful for the financial support by EMBRAPACafé, UCB, CAPES, CNPq and FAPEMIG.

\section{References}

[1] H. Ashihara, A.M. Monteiro, F.M. Gillies, A. Crozier, Biosynthesis of caffeine in leaves of coffee. Plant Physiol. (1996) 747-753.

[2] L. Mondolot, P. La Fisca, B. Buatois, E. Talansier, A. Kochko, C. Campa, Evolution in caffeoylquinic acid content and histolocalization during Coffea canephora leaf development. Ann. Bot. (2006) 33-40.

[3] B. Bertrand, B. Guyot, F. Anthony, P. Lashermes, Impact of the Coffea canephora gene introgression on beverage quality of $C$. arabica. Theor. Appl. Genet. (2003) 387-394.

[4] G. Bytof, S.-E. Knopp, D. Kramer, B.R. Breitenstein, J.H.W. Bergervoet, S. Groot, D. Selmar, Transient occurrence of seed germination processes during coffee post-harvest. Ann. Bot. (2007) 61-66.

[5] E.A. Amaral da Silva, P.E. Toorop, J. Nijsse, J.D. Bewley, H.W.M. Hilhorst, Exogenous gibberellins inhibit coffee (Coffea arabica cv Rubi) seed germination and cause cell death in the embryo. J. Exp. Bot. (2005) 1029-1038.

[6] J. Bustamante-Porras, C. Campa, V. Poncet, M. Noirot, T. Leroy, S. Hamon, A. Kochko, Molecular characterization of an ethylene receptor gene (CcETR1) in coffee trees, its relationship with fruit development and caffeine content. Mol. Genet. Genomics (2007) 701-712.

[7] S. Chen, A.C. Harmon, Advances in plant proteomics. Proteomics (2006) 5504-5516.

[8] S. Viswanathan, Mustafa Unlu, J.S. Minden, Two-dimensional difference gel electrophoresis. Nat. Prod. (2006) 1350-1358.

[9] P. Montavon, A.F. Mauron, E. Duruz, Changes in green coffee protein profiles during roasting. J. Agric. Food Chem. (2003) 2335-2343. 
[10] R. De Mot, J. Vanderleyden, Application of two dimensional protein analysis for strain fingerprinting and mutant analysis of Azospirillum species. Can. J. Microbiol. (1989) 960-967.

[11] M.M. Bradford, A rapid and sensitive method for the quantitation of microgram quantities of protein utilizing the principle of protein-dye binding. Anal. Biochem. (1976) 248-254.

[12] A. Gorg, W. Postel, S. Gubther, The current state of two-dimensional electrophoresis with immobilized pH gradients. Eletrophoresis (1988) 531-546.

[13] U.K. Laemmli, Cleavage of structural proteins during the assembly of the head of the bacteriophage T4. Nature (1970) 680-685.

[14] H. Blum, H. Beier, H.J. Gross, Improved silver staining of plant protein: RNA and DNA in polyacrylamide gels. Electrophoresis (1987) 93-98.

[15] A. Shevchenko, M. Wilm, O. Vorm, M. Mann, Mass spectrometric sequencing of proteins from silver stained polyacrylamide gels. Anal. Chem. (1996) 850-858.

[16] M. Golovkin, A.S.N. Reddy, Structure and expression of a plant U1 snRNP 70L gene: alternative splicing of U1 snRNP 70K Pre-mRNAs produces two different transcripts. Plant Cell (1996) 1421-1435.

[17] B.A. Hanley, M.A. Schuler, cDNA cloning of U1, U2, U4 and U5snRNA families expressed in pea nuclei. Nucleic Acids Res. (1991) 1861-1869.

[18] V.L. Van Santen, R.A. Spritz, Splicing of plant pre-mRNAs in animal systems and vice versa. Gene (1987) 253-265.

[19] B.A. Hanley, M.A. Schuler, Developmental expression of plant snRNAs. Nucleic Acids Res. (1991) 6319-6325.

[20] S. Abel, T. Kiss, F. Solymosy, Molecular analysis of eight U1 RNA genes candidates form tomato that could potentially be transcribed into U1 RNA sequence variants differing from each other in similar regions of secondary structure. Nucleic Acids Res. (1989) 6329-6337.

[21] M.A. Musci, D.B. Egeland, M.A. Schuler, Molecular comparison of monocot and dicot U1 and U2 snRNAs. Plant J. (1992) 589-599.

22] N. Panté, A. Jarmolowski, E. Izaurralde, U. Sauder, W. Baschong, I.W. Mattaj, Visualizing nuclear export of different classes of RNA by electron microscopy. RNA (1997) 498-513.

[23] C. Guthrie, Messenger RNA splicing in yeast: clues to why the spliceosome is a ribonucleoprotein. Science (1991) 157-163.

[24] T. O'Brien, The dubious origins of pleurocarpous mosses: evidence from the chloroplast genes atpB, rbcL, rps4 and trnL. Biol. Sci. (2001) NCBI direct submission. http://www.ncbi.nlm.nih.gov/entrez/viewer.fcgi?db=protein\&id=32563501.

[25] C. Lemaire, F.-A. Wollmang, The chloroplast ATP synthasein Chlamydomonas reinhardtii. J. Biol. Chem. (1988) 10235-10242.

[26] L.M. Amzel, P.L. Pedersen, Proton ATPases: structure and mechanism. Annu. Rev. Biochem. (1983) 801-824.
[27] S. Xing, M.G. Rosso, S. Zachgo, ROY1, a member of the plant glutaredoxin family, is required for petal development in Arabidopsis thaliana. Development (2005) 1555-1565.

[28] T.E. Hanson, F.R. Tabita, A ribulose-1,5-bisphosphate carboxylaseyoxygenase (RubisCO)-like protein from Chlorobium tepidum that is involved with sulfur metabolism and the response to oxidative stress. Proc. Nat. Acad. Sci. (2001) 4397-4402.

[29] E.J. Yanga, Y.A. Oh, E.S. Lee, A.R. Park, S.K. Cho, Y.J. Yoo, O.K. Park, Oxygenevolving enhancer protein 2 is phosphorylated by glycine-rich protein 3/wallassociated kinase 1 in Arabidopsis. Biophys. Res. Commun. (2003) 862-868.

[30] B. Karpiniska, M. Karlsoon, M. Srivastava, A. Stenberg, J. Schrader, F. Sterky, R. Bhalerae, G. Wingsle, MYB transcription factors are differentially expressed and regulated during secondary vascular tissue development in hybrid aspen. Plant Mol. Biol. (2004) 255-270.

[31] T. Arioli, L. Peng., A.S. Betzner, et al., Molecular analysis of cellulose biosynthesis in Arabidopsis. Science (1998) 717-720.

[32] Z.H. Ye, Vascular tissue differentiation and pattern formation in plants. Annu. Rev. Plant Biol. (2002) 183-202.

[33] J. Bogs, F.W. Jaffe, A.M. Takos, A.A.R. Walker, S.P. Robinson, The grapevine transcription factor VvMyBPA1 regulates proanthocyanidin synthesis during fruit development. Plant Physiol. (2007) 1347-1361.

[34] T. Kroj, JJ. Rudd, T. Nurnberger, Y. Gaebler, J. Lee, D. Scheel, Mitogen-activated protein kinases play an essential role in oxidative burst-independent expression of pathogenesis-related genes in parsley. J. Biol. Chem. (2003) 2256-2264.

[35] C. Widmann, S. Gibson, M.B. Jarpe, Mitogen-activated protein kinase: conservation of a three-kinase module from yeast to human. Physiol. Rev. (1999) 143-180.

[36] M.T. Gil-Agusti, N. Campostrini, L. Zolla, C. Ciambella, C. Invernizzi, P.G. Righetti, Two-dimensional mapping as a tool for classification of green coffee bean species. Proteomics (2005) 710-718.

[37] L.L. Koshino, C.P. Gomes, L.P. Silva, M.T. Eira, C. Bloch Jr., O.L. Franco, A. Mehta Comparative proteomical analysis of zygotic embryo and endosperm from Coffea arabica seeds. J. Agric. Food Chem. (2008) 10922-10926.

[38] R.D. De Castro, P. Marraccini, Cytology, biochemistry and molecular changes during coffee fruit development. Braz. J. Plant Physiol. (2006) 175-199.

[39] I. Nishida, R. Swinhoe, A.R. Slabas, N. Murata, Cloning of Brassica napus CTP phosphocholine cytidylyltransferase cDNAs by complementation in a yeast cct mutant. Plant Mol. Biol. (1996) 205-211.

[40] R. Inatsugi, M. Nakamura, I. Nishida, Phosphatidylcholine biosynthesis at low temperature: differential expression of CTP: phosphorylcholine cytidylyltransferase isogenes in Arabidopsis thaliana. Plant Cell Physiol. (2002) 1342-1350. 